\title{
Analisis Morfotektonik dan Pemetaan Geologi pada Identifikasi Sesar Permukaan di daerah Plampang, Pulau Ngali dan Pulau Rakit, Provinsi Nusa Tenggara Barat
}

\author{
Supartoyo'. Hadi Suntoko², Abimanyu Bondan², Euis Etty Alhakim² \\ ${ }^{1}$ Pusat Vulkanologi dan Mitigasi Bencana Geologi, Badan Geologi, Jl. Diponegoro, Bandung \\ ${ }^{2}$ Pusat Kajian Sistem Energi Nuklir,BATAN, JI. Kuningan Barat, Jakarta Selatan
}

\begin{tabular}{l}
\hline INFORMASI ARTIKEL \\
\hline Riwayat Artikel: \\
Diterima: \\
16 Juni 2019 \\
Diterima dalam bentuk revisi: \\
26 Juni 2019 \\
Disetujui: \\
24 Juli 2019
\end{tabular}

Kata kunci:

Sesar permukaan

Bahaya gempabumi

Pemetaan geologi

\begin{abstract}
ABSTRAK
ANALISIS MORFOTEKTONIK DAN PEMETAAN GEOLOGI PADA IDENTIFIKASI SESAR PERMUKAAN DI DAERAH PLAMPANG, PULAU NGALI DAN PULAU RAKIT, PROVINSI NUSA TENGGARA BARAT. Kebutuhan listrik di Indonesia semakin meningkat terutama di Indonesia bagian tengah dan timur, maka diperlukan pembangkit listrik untuk memasok kebutuhan tersebut, dan wacananya adalah Pembangkit Listrik Tenaga Nuklir (PLTN). Provinsi Nusa Tenggara Barat (NTB) merupakan salah satu kawasan strategis yang memerlukan listrik terutama untuk industri pariwisata, namun demikian, daerah NTB rawan terhadap bahaya gempabumi, yaitu guncangan dan bahaya ikutan, seperti retakan tanah, likuifaksi dan gerakan tanah atau longsor. Sesar permukaan yang termasuk sesar aktif adalah salah satu jenis bahaya gempabumi yang harus dihindari. Penyelidikan ini bertujuan untuk mengidentifikasi adanya sesar permukaan di daerah NTB, yaitu di Plampang, Pulau Ngali, Pulau Rakit. Metodologi yang digunakan meliputi pengamatan morfologi, morfotektonik, singkapan batuan, dan unsur-unsur pensesaran permukaan, dan pemetaan geologi. Hasil penyelidikan menunjukkan tidak terindikasi adanya sesar permukaan di daerah Plampang, Pulau Ngali, Pulau Rakit, namun hanya didapatkan beberapa kelurusan dan kekar dan indikasi sesar minor saja. Berdasarkan hasil analisis dapat disimpulkan bahwa tidak ditemukan adanya pensesaran permukaan di NTB khususnya di daerah Plampang, Pulau Ngali, dan Pulau Rakit.
\end{abstract}

\begin{abstract}
MORFOTECTONIC ANALYSIS AND GEOLOGICAL MAPPING ON IDENTIFICATION OF SURFACE FAULTS IN PLAMPANG, NGALI AND RAKIT ISLANDS, WEST NUSA TENGGARA PROVINCE. Electricity needs in Indonesia especially in central and eastern Indonesia are increasing. Accordingly it is necessary to identify a number of regions as potential sites for power plants, including the Nuclear Power Plant (NPP) which are safe from external events. Province of NTB is one of strategic area that electricity needs to support tourism and industry. Surface faulting is an active faults are classified as one type of earthquake hazard that must be avoided when an earthquake occurs. The other earthquake hazards include earthquake shaking and collateral hazards including ground fracturing, liquefaction and landslides. This research objective is to identify the surface faults of Plampang area, Ngali Island, Rakit Island by using methods of geological mapping and morphotectonic mapping analysis. Based on this method there was no indication of surface faulting in Plampang area, Ngali Island, Rakit Island. However, several lineament joint and indication of minor faults were identified in the study area but no evidence of surface faulting- Analysis result it can be concluded that there is no surface enlargement in Ngali island, Rakit Island and Plampang area

Keywords: surface faulting, earthquake hazard, geological mapping
\end{abstract}

(c) 2019 Jurnal Pengembangan Energi Nuklir. All rights reserved

\section{PENDAHULUAN}

Sesar permukaan (surface faulting) berbeda pengertian dan dampaknya dengan sesar pada umumnya. Sesar permukaan terbentuk berkaitan dengan kejadian gempabumi dan merupakan salah satu bahaya gempabumi. Sesar (fault) merupakan retakan atau sistem retakan pada batuan yang telah mengalami pergerakan[1]. Apabila retakan pada batuan belum bergerak atau bergeser

${ }^{*}$ Penulis korespondensi.

E-mail:supartoyo@gmail.com disebut kekar (joint). Suatu sesar dapat berupa bidang sesar atau rekahan tunggal, tetapi lebih sering membentuk jalur atau garis dan membentuk zona sesar. Zona sesar merupakan kumpulan beberapa sesar penyerta yang mengikuti atau berkaitan dengan sesar utama. Sesar dihasilkan dari deformasi yang bersifat brittle. Sesar permukaan tidak mencirikan struktur penyerta seperti pada sesar berumur Tersier, karena media yang dilalui sesar permukaan adalah tanah, sehingga tidak akan ditemukan adanya gores-garis, kekar gerus, kekar tarik, mikrofold, dan lain-lain. 
Secara kinematik sesar dapat dibedakan menjadi tiga, yaitu sesar normal atau turun, geser atau mendatar dan naik. Berdasarkan tingkatan aktivitasnya, sesar dapat dibedakan menjadi tiga, yaitu sesar aktif (active fault), sesar berpotensi aktif (potential active fault), dan sesar tidak aktif (inactive fault). Menurut California State Mining and Geology Board Classification, sesar aktif adalah sesar yang pernah bergerak pada kurun waktu 10.000 tahun hingga 2 juta tahun yang lalu[2]. Sesar berpotensi aktif adalah sesar yang pernah bergerak pada kurun waktu 2 juta tahun yang lalu.

Sesar tidak aktif adalah sesar yang tidak pernah bergerak dalam kurun waktu 2 juta tahun yang lalu. Terkait aktivitas sesar, terdapat sesar kapabel (capable fault) yang digunakan oleh IAEA (International Atomic Energy Agency) dalam persiapan lokasi tapak untuk pembangunan instalasi nuklir[3]. Menurut peraturan BAPETEN (2013), sesar atau patahan kapabel adalah suatu patahan yang mempunyai potensi signifikan untuk terjadinya pergeseran pada atau dekat permukaan tanah[4]. Terdapat cara untuk mengetahui apakah suatu sesar aktif atau tidak, diantaranya adalah dengan cara geologi, metode GPS dan metode seismologi[5,6,7].

Sesar kapabel merupakan parameter yang dipertimbangkan terutama dalam penempatan instalasi termasuk Pembangkit Listrik Tenaga Nuklir (PLTN). Penempatan instalasi tersebut harus menghindari garis atau jalur dan zona sesar, baik sesar kapabel, sesar aktif atau sesar berpotensi aktif untuk menghindari risiko yang mungkin timbul akibat pergerakannya. Pergerakan sesar aktif merupakan salah satu jenis bahaya gempabumi yang dikenal sebagai sesar permukaan. Sesar permukaan akan memotong semua obyek yang terdapat di permukaan tanah. Tak ada satupun bangunan yang bisa selamat dari bahaya pergerakan sesar aktif.

Bahaya gempabumi lainnya adalah efek guncangan (earthquake shaking) dan bahaya ikutan (collateral hazard). Efek guncangan dinyatakan dalam nilai percepatan gempabumi atau peak ground acceleration (pga) dalam satuan gal $\left(\mathrm{cm} / \mathrm{det}^{2}\right)$ atau $\mathrm{g}$ (gravitasi, $\mathrm{m} / \mathrm{det}^{2}$ ). Nilai pga dapat dihitung pada batuan dasar atau tanah permukaan. Bahaya ikutan gempabumi meliputi retakan tanah (ground fracturing), gerakan tanah (landslide), dan likuifaksi (liquefaction) yang harus dihindari dalam rencana pembangunan infrastruktur. Daerah Lombok dan Sumbawa telah mengalami gempabumi dan tsunami yang diakibatkan oleh sesar naik Flores[8,9]. Berdasarkan peta pga Indonesia dengan kala ulang 2500 tahun, NTB khususnya daerah telitian memiliki nilai pga sedang atau 0.3$0.4 \mathrm{~g}[10,11]$.

Penelitian ini bertujuan untuk mengidentifikasi adanya pensesaran permukaan di NTB khususnya di daerah Plampang, Pulau Rakit dan Pulau Ngali sebagai kajian awal penentuan lokasi PLTN di Provinsi NTB, sehingga daerah tersebut dapat dinyatakan aman dari bahaya sesar permukaan.

\section{METODOLOGI}

Pengamatan atau survei lapangan dilakukan di daerah Plampang, Pulau Ngali, dan Pulau Rakit (Gambar 1).

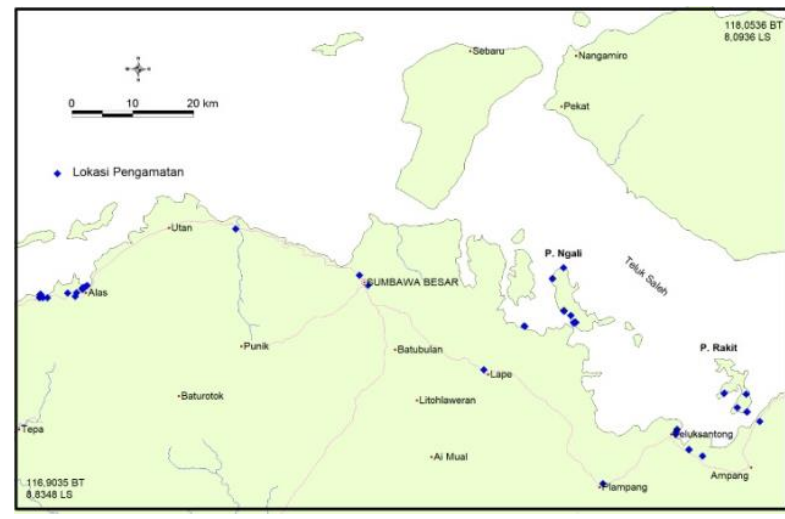

Gambar 1. Peta lokasi pengamatan lapangan di Pulau Ngali, Pulau Rakit, dan daerah Plampang

Pulau Ngali dan Rakit ditempuh menggunakan kapal kecil, untuk menuju Pulau Ngali ditempuh dari pelabuhan nelayan Labuan Tratak sedangkan ke Pulau Rakit dari pelabuhan nelayan Labuan Jambu.

Pengukuran unsur-unsur sesar permukaan digunakan beberapa peralatan survey seperti: GPS (Global Positioning System) tipe navigasi, kompas geologi, meteran, kamera digital, bahan kimia larutan $\mathrm{HCl}$, peta dasar, dan alat tulis.

Metode yang digunakan adalah analisis pensesaran permukaan dengan melakukan pengamatan morfologi, morfotektonik, singkapan batuan, dan unsur-unsur pensesaran permukaan. Selain itu melakukan identifikasi 
dampak akibat kejadian gempabumi Lombok tanggal 29 Juli, 5 dan 19 Agustus 2018 di daerah penyelidikan.

Jejak pensesaran permukaan akan difokuskan pada pengamatan kenampakan bentuk lahan (landform), berupa kelurusan morfologi ataupun lembah, gawir sesar (fault scarp), lembah linier (linier valley), pergeseran atau offset (sungai, bukit dan obyek lainnya), zona muka pegunungan (mountain front), depresi yang terbentuk sepanjang zona sesar, saddle, pressure ridge, tonjolan tektonik (tectonic bulge), sungai teranyam, dan lain lain (Gambar 2).

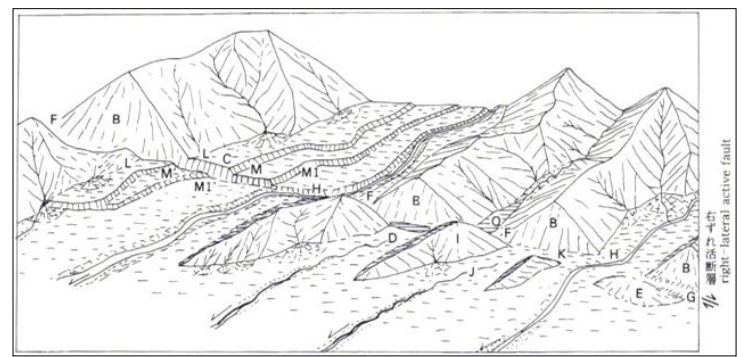

Gambar 2. Bentuk lahan yang terbentuk berkaitan dengan sesar mendatar menganan[12].

Keterangan: $\mathrm{B}=$ perbukitan faset segitiga, $\mathrm{C}=$ gawir sesar, $\mathrm{D}=$ sagpond, $\mathrm{E}=$ onjolan tektonik (tectonic bulge), $\mathrm{F}=$ fault saddle, $\mathrm{G}=$ graben, $\mathrm{H}=$ pergeseran sungai, $\mathrm{I}=$ shutter ridge, $\mathrm{J}=$ sungai teranyam/behaided stream, $\mathrm{K}=$ gap angin/ wind gap, $\quad \mathrm{L}-\mathrm{L}$ '= pergeseran pegunungan muka, $\mathrm{M}-\mathrm{M}$ '= pergeseran teras, $\mathrm{Q}=$ fault pond

Fokus pengamatan bentuk lahan di daerah yang diperkirakan merupakan jalur atau garis sesar dan juga zona sesar. Gambar 3 memperlihatkan sesar permukaan dengan pergeseran mengiri (sinistral offset) sebesar $515 \mathrm{~cm}$ di jalan Cemara Indah, Kota Palu akibat gempabumi 28 September 2018.

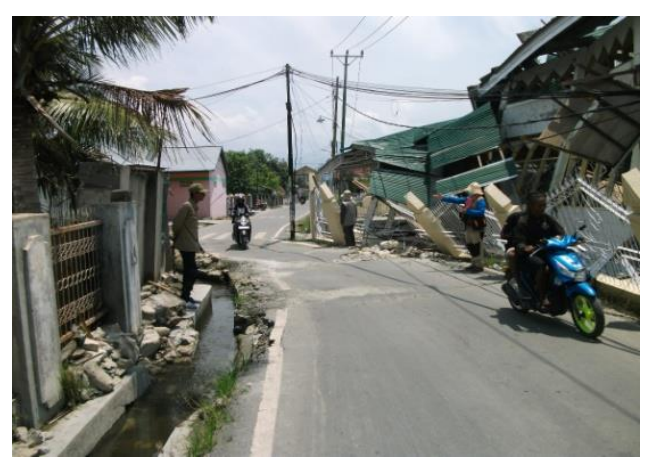

Gambar 3. Contoh bahaya gempabumi berupa sesar permukaan, yaitu pergeseran mengiri (sinistral offset) sebesar $515 \mathrm{~cm}$ di Jalan Cemara Indah, Kota Palu sebagai indikasi sesar permukaan akibat gempabumi tanggal 28 September 2018 [15].
Selanjutnya dilakukan verifikasi hasil pengamatan lapangan dengan data citra satelit untuk melihat pola kelurusan, data kegempaan, data geofisika (gaya berat dan magnetik), data penampang geofisika (seismik, Ground Penetration Radar/ GPR, geolistrik). Data citra satelit yang dianalisis sebaiknya yang mempunyai resolusi tinggi. Data tersebut penting untuk memverifikasi dan melakukan analisis berdasarkan lokasi data permukaan yang dicurigai terdapat jalur sesar permukaan atau zona sesar permukaan.

Pada dasarnya metode yang digunakan tersebut mendukung untuk melakukan kajian paleoseismologi, yaitu suatu kajian untuk mempelajari kejadian gempabumi masa lampau meliputi dimensi besaran, waktu dan perulangannya[13,14]. Metode ini pada umumnya dengan melakukan pembuatan paritan (trenching) pada lokasi yang dicurigai sebagai jalur sesar permukaan atau sesar aktif. Untuk menentukan lokasi paritan dilakukan kajian menggunakan metode tersebut.

\section{HASIL DAN PEMBAHASAN}

\subsection{Data Lapangan (Singkapan Batuan, Morfologi, Morfotektonik, dan Unsur-Unsur Pensesaran Permukaan)}

Daerah Labuan Tratak didiominasi oleh batuan alterasi jenis kaolinit dan argilic yang berwarna putih (Gambar 4).

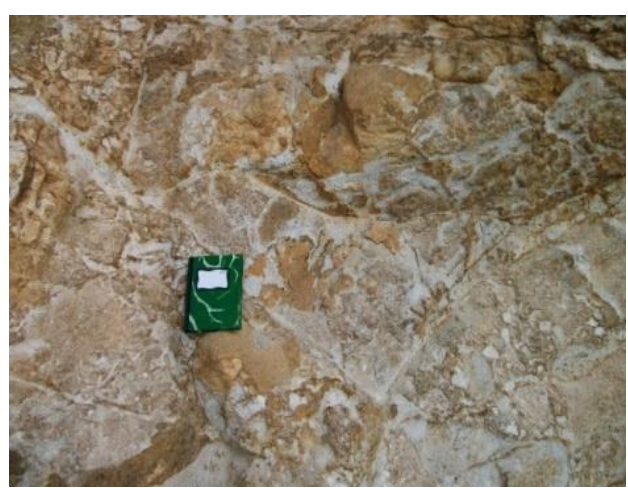

Gambar 4. Singkapan batuan alterasi jenis kaolinit dan argilic di daerah Labuan Tratak.

Pulau Ngali didominasi oleh batugamping bioklatik dan kristalin, selain itu juga ditemukan konglomerat dan endapan Kuarter berupa endapan pantai. Batu gamping bioklastik berwarna kehitaman tersusun oleh pecahan 
koral, ganggang dan biota laut dengan kedudukan relatif horizontal (Gambar 5). Pada konglomerat juga ditemukan kekar berarah NE-SW dan E-W (Gambar 6).

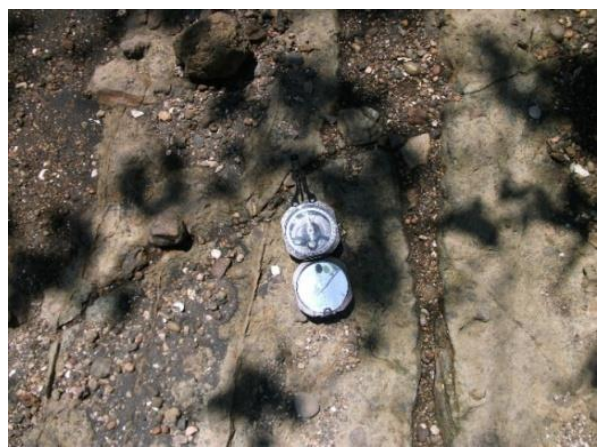

Gambar 5. Singkapan batugamping dengan kekar berarah utara-selatan di Pulau Ngali

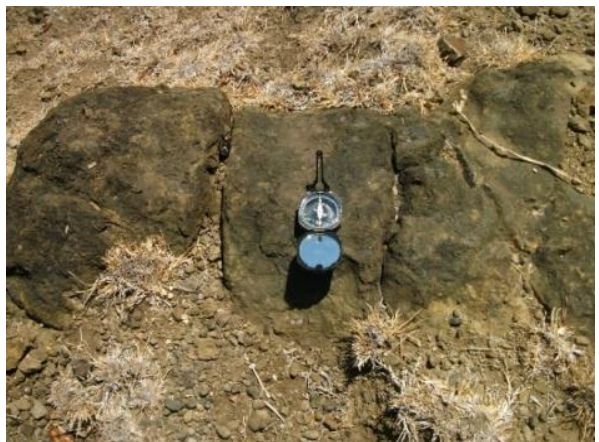

Gambar 6. Singkapan konglomerat dengan kekar berarah utara-selatan dan relatif barat - timur di Pulau Ngali.

Teras ditemukan pada bagian barat Pulau Ngali pada endapan abu vulkanik dan endapan pantai (Gambar 7). Tebal endapan pantai pada bagian bawah $25 \mathrm{~cm}$ dan tebal abu vulkanik di bagian atasnya $28 \mathrm{~cm}$.

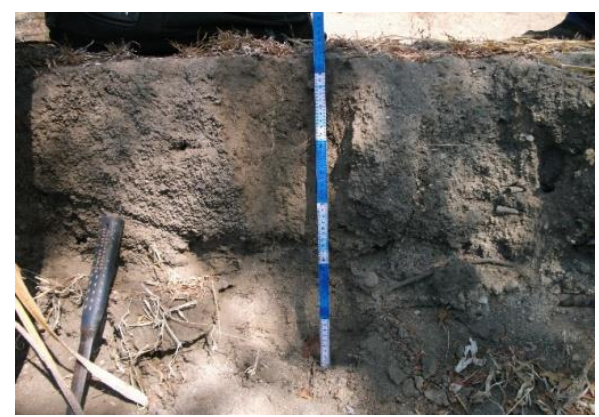

Gambar 7. Singkapan abu vulkanik, bagian atas tuff halus setebal $29 \mathrm{~cm}$ dan bagian bawah tuff pasiran setebal 25 cm di Pulau Ngali

Lokasi pengamatan di Pulau Rakit didominasi oleh batuan lava, sebagian konglomerat, pasir teroksidasi, abu vulkanik dan endapan pantai. Lava berwarna kehitaman, berbentuk fragmen- fragmen, komposisi andesitik dan terdapat kekar berarah N-S, E-W (Gambar 8 dan 9).

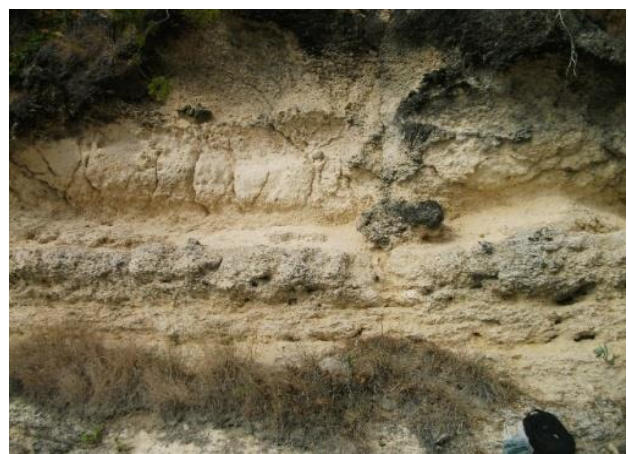

Gambar 8. Singkapan batugamping berlapis dengan kedudukan relative horizontal di bagian barat Pulau Ngali.

Abu vulkanik berwarna abu-abu keruh, lepas, ukuran butir halus, tebal $30 \mathrm{~cm}$ dan membentuk teras (Gambar 9).

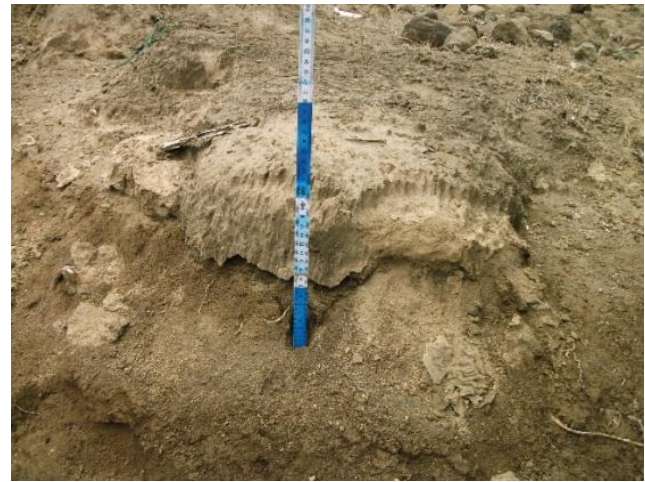

Gambar 9. Singkapan abu vulkanik dengan tebal $30 \mathrm{~cm}$ di Pulau Rakit.

Konglomerat setempat berwarna kecoklatan, bentuk fragmen dan matrik membulat tanggung, fragmen dan matrik andesit dan pasir. Pasir teroksidasi setempat berwarna coklat tua, ukuran butir pasir kasar (Gambar 10).

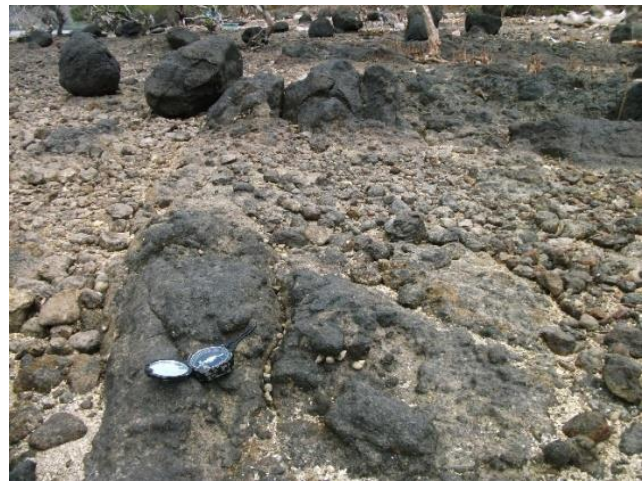

Gambar 10. Singkapan lava dengan kekar berarah barat - timur di Pulau Rakit. 
Abu vulkanik berwarna abu-abu keruh, lepas, ukuran butir halus, tebal $30 \mathrm{~cm}$ dan membentuk teras (Gambar 11).

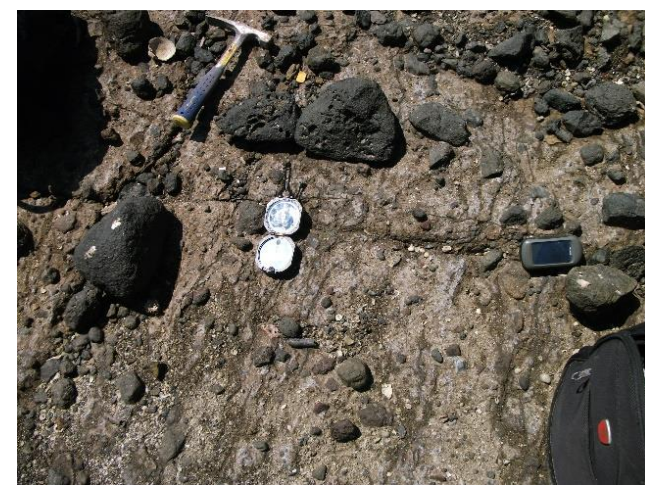

Gambar 11. Singkapan konglomerat dengan kekar arah barat - timur di Pulau Rakit.

Lokasi pengamatan di daerah Plampang (Pulau Sumbawa) tersusun oleh batuan beku andesit, warna abu-abu kecoklatan, kondisi segar (fresh), masif, fanerik sedang, holokristalin, inequigranular, komposisi kuarsa lebih 10\%, dan terdapat kekar berarah NNE-SSW. Pada tanggal 29 Juli, 5 dan 19 Agustus 2018 terjadi gempabumi, dan guncangan paling kuat adalah gempabumi pada tanggal 19 Agustus 2018 dengan skala IV MMI dan menyebabkan dua rumah mengalami retakan dinding di daerah Plampang.

Lokasi pengamatan daerah Plampang bagian utara ditemukan batuan ubahan (altered rock) berwarna abu-abu hingga abu-abu kecoklatan, jenis alterasi argillic dan juga bongkahan andesit, serta kekar berarah $\mathrm{N}-\mathrm{S}$ dan NW-SE. Di bagian selatan daerah Plampang ditemukan singkapan batuan ubahan berwarna putih kecoklatan, terdapat kekar, alterasi jenis kaolinisasi dan argillic pada kekar. Terdapat indikasi dua sesar minor dengan kedudukan $\mathrm{N} 80^{\circ} \mathrm{E} / 72^{\circ}$ dan $\mathrm{N} 83^{\circ} \mathrm{E} / 85^{\circ}$ pada batuan alterasi tersebut. Selain itu dilakukan juga pengamatan lapangan dampak kejadian gempabumi Lombok yang terjadi pada tanggal 19 Agustus 2018 di daerah Kecamatan Alas dan Alas Barat.

Lokasi episenter kejadian gempabumi tersebut terletak lebih dekat ke Pulau Sumbawa dibandingkan kejadian gempabumi tanggal 29 Juli 2018 dan 5 Agustus 2018, sehingga efek guncangan terasa lebih kuat di Pulau Sumbawa.

\subsection{Pembahasan}

Kelurusan berarah Utara - Selatan yang terdapat pada bagian barat Pulau Ngali bukan merupakan indikasi keberadaan struktur geologi, namun diakibatkan oleh perbedaan kekerasan batuan antara endapan pantai dan batugamping (Gambar 4). Adanya kekar pada batugamping yang berarah $\mathrm{N}-\mathrm{S}$ dan pada konglomerat yang berarah NE-SW dan E-W bukan mengindikasikan keberadaan struktur geologi, karena ditemukan dalam jumlah sedikit dan tidak ditemukan adanya liniasi dan data struktur penyerta lainnya yang membuktikan pergerakan suatu sesar, seperti gawir sesar, seretan, gores-garis, kekar gerus dan kekar tarik. Teras yang ditemukan pada bagian barat Pulau Ngali pada endapan abu vulkanik dan endapan pantai, terbentuk saat ini dan bukan indikasi tektonik aktif karena terbentuk akibat proses abrasi.

Kekar yang terdapat di Pulau Rakit, yaitu pada batuan lava bukan mengindikasikan keberadaan struktur geologi, karena ditemukan dalam jumlah sedikit dan tidak ditemukan adanya liniasi dan data struktur penyerta lainnya. Kekar ini berkaitan dengan proses pendinginan dari batuan lava. Teras yang ditemukan pada bagian barat Pulau Ngali hanya setempat, serta terdapat pada abu vulkanik dan endapan pantai bukan indikasi tektonik aktif karena terbentuk akibat proses abrasi. Teras dapat mencirikan proses aktif tektonik apabila mengalami pergeseran (offset), dalam skala luas yang mencirikan adanya pengangkatan, dan berpasangan (umumnya pada teras sungai)[1,2]. Kekar yang terdapat di daerah Plampang Pulau Sumbawa tidak mengindikasikan keberadaan struktur geologi, karena ditemukan dalam jumlah sedikit dan tidak ditemukan adanya liniasi dan data struktur penyerta lainnya.

Dampak dari kejadian gempabumi skala IV MMI (Modified Mercally Intensity) di Pulau Ngali, Pulau Rakit dan daerah Plampang berupa kerusakan ringan, retakan dinding beberapa bangunan rumah. Pada bagian selatan daerah Plampang terdapat indikasi dua sesar minor pada batuan ubahan. Kedudukan sesar minor pertama adalah $\mathrm{N} 80^{\circ} \mathrm{E} / 72^{\circ}$ dan kedua $\mathrm{N} 83^{\circ} \mathrm{E} / 85^{\circ}$. Untuk menarik garis sesar ini harus dilakukan pemetaan detil sesuai dengan arah dari jurus (strike) sesar minor. Sesar minor pada batuan ubahan ini berumur Tersier dan tidak memotong endapan Kuarter, sehingga bukan merupakan sesar permukaan. Berbeda dengan kejadian gempabumi Lombok tanggal 19 
Agustus 2018 yang mencapai skala VI MMI menyebabkan sejumlah bangunan mengalami kerusakan ringan dan berat di kedua kecamatan. Bahaya ikutan gempabumi yang terjadi adalah likuifaksi dan retakan tanah berarah timur laut-barat daya di Kampung Bugis, Desa Labuan Mapin, Kecamatan Alas Barat (Gambar 12 dan 13).

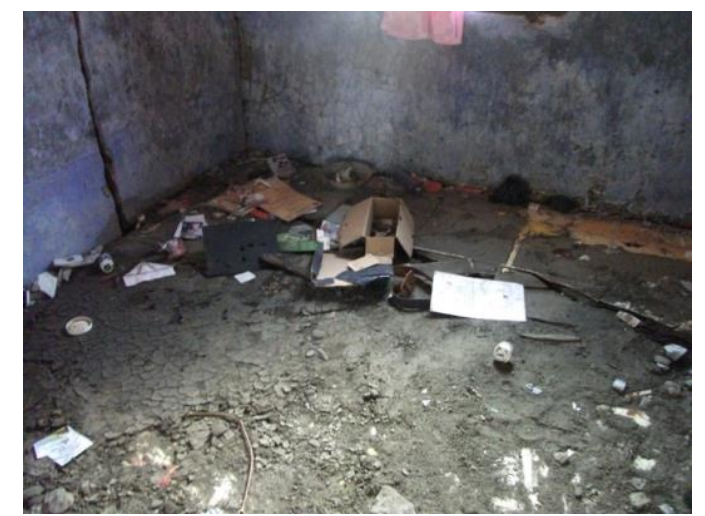

Gambar 12. Likuifaksi mengakibatkan kerusakan rumah penduduk di Kampung Bugis, Desa Labuan Mapin.

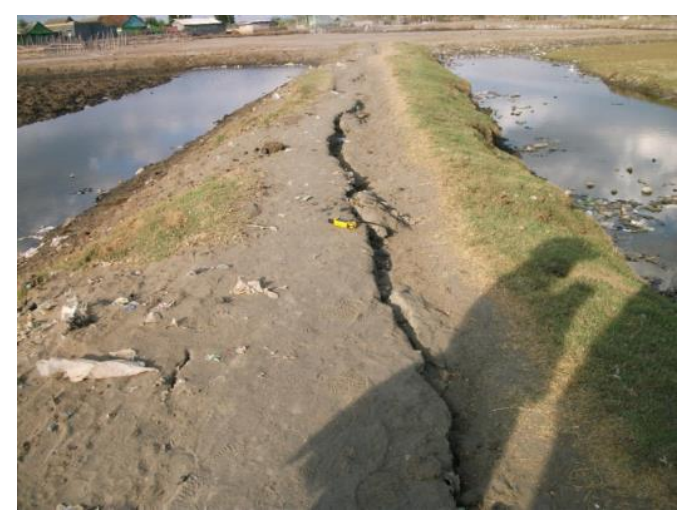

Gambar 13. Retakan tanah berarah timur laut - barat daya di Kampung Bugis, Desa Labuan Mapin, Kecamatan.

Likuifaksi dicirikan adanya material pasir halus yang keluar dari celah retakan tanah. Retakan tanah yang terbentuk bukan merupakan sesar permukaan (surface fault rupture) karena terdapatnya setempat dan tidak terlihat adanya pergeseran (offset).

Hasil survei menunjukkan tidak ada indikasi adanya sesar permukaan di Pulau Ngali, Pulau Rakit dan daerah Plampang. Kejadian gempabumi yang melanda daerah NTB pada bulan Juli dan Agustus 2018, yang guncangannya cukup kuat pada skala IV - V MMI terjadi di Pulau Ngali, Pulau Rakit dan daerah Plampang (Gambar 14).

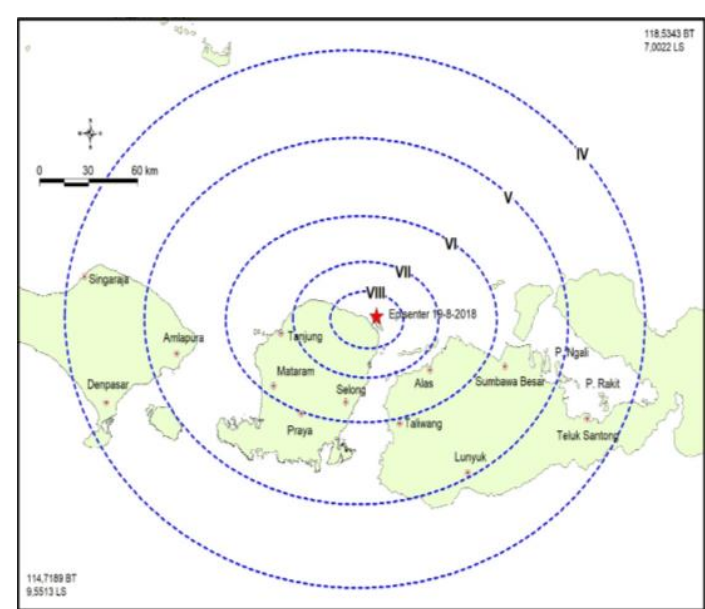

Gambar 14. Peta intensitas gempabumi tanggal 19 Agustus 2018 berdasarkan pengamatan lapangan dan data BMKG.

Berdasarkan letak dari sumber gempabumi sesar naik Flores pada bagian utara, Plampang terletak paling jauh disusul Pulau Rakit dan terdekat adalah Pulau Ngali. Data kegempaan katalog USGS (tahun 1900 2012)[16] dan katalog dari Engdahl (tahun 2007)[18], tidak ditemukan adanya sebaran episenter gempabumi dengan kedalaman dangkal pada lokasi daerah penyelidikan (Gambar 15).

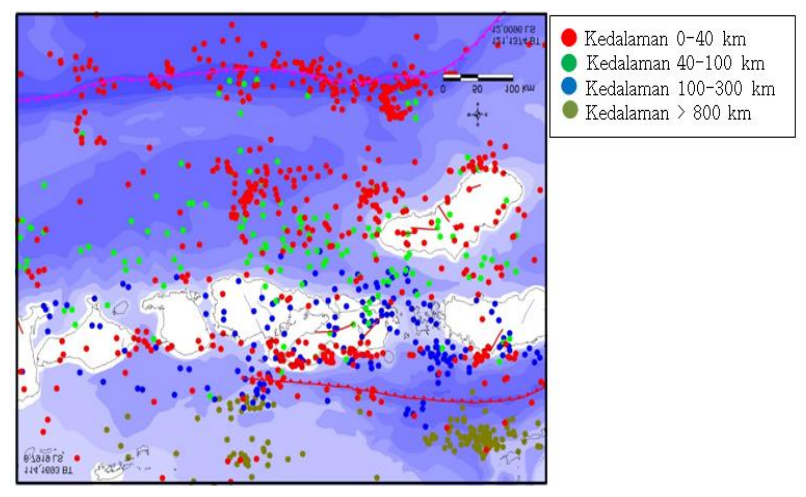

Gambar 15. Sebaran kegempaan tahun 1900 hingga 2014 [18].

Hal ini didukung juga data sejarah bahwa tidak tercatat adanya gempabumi merusak di Pulau Ngali, Pulau Rakit dan daerah Plampang, wilayah Pulau Sumbawa sejak tahun 1612 hingga sekarang[16]. Data Pusat Gempa Nasional atau Pusgen KPUPR (tahun 2017) tidak melaporkan adanya sesar aktif di daerah Teluk Saleh (Gambar 16), hanya sesar naik Flores pada bagian utara, sesar mendatar di Selat Alas dan sesar mendatar di selatan Pulau Sumbawa. PSG Badan Geologi (2018) mengidentifikasi adanya sesar naik melewati 
Teluk Saleh yang ditafsirkan dari kelurusan data anomali sisa pada basement (Gambar 17).

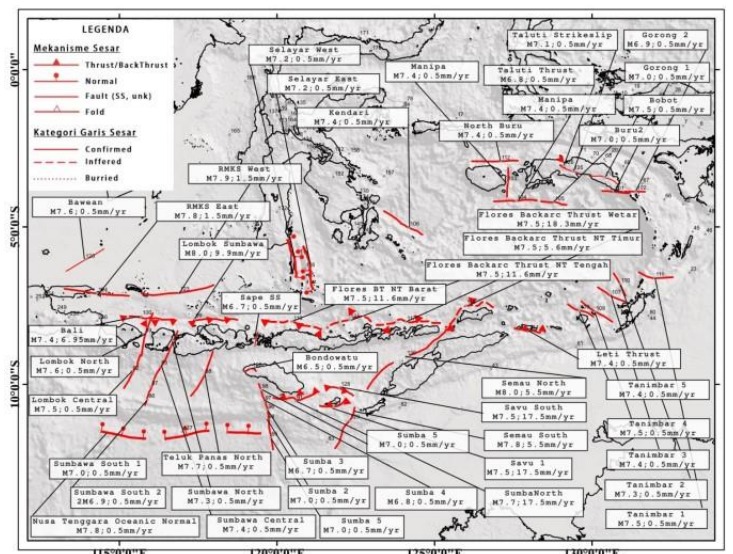

Gambar 16. Sumber-sumber gempabumi daerah NTB dan sekitarnya[19]

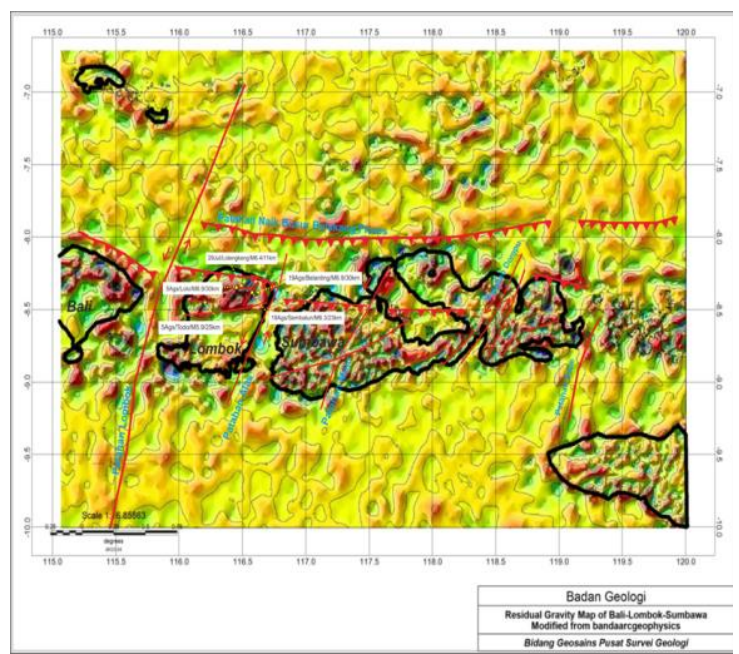

Gambar 17. Sebaran struktur geologi berupa sesar di daerah NTB dan sekitarnya ditafsirkan dari data gaya berat [20].

Berdasarkan data batimetri tidak terlihat adanya kelurusan sepanjang sesar naik di Teluk Saleh dan untuk memastikan keberadaan sesar tersebut, perlu dilakukan penelitian untuk mengetahui ada tidaknya sesar aktif secara detil. Data seismik refleksi yang berarah tegak lurus atau berarah NNE-SSW akan membantu mengidentifikasi apakah sesar ini memotong endapan Kuarter. Data kegempaan mikro dan mekanisme sumber (focal mechanism) akan membantu mengidentifikasi keberadaan dan tingkat aktivitas sesar naik tersebut.

Berdasarkan analisis menggunakan data geologi dan seismotektonik regional, data sebaran pusat gempabumi dan kejadian gempabumi merusak, serta hasil pengamatan lapangan dapat disimpulkan tidak ditemukan adanya indikasi pensesaran permukaan pada lokasi daerah penyelidikan, yaitu daerah Plampang, Pulau Ngali dan Pulau Rakit.

\section{KESIMPULAN DAN SARAN}

\subsection{Kesimpulan}

Data sejarah gempa memperlihatkan bahwa kejadian gempabumi yang paling kuat terasa di Pulau Ngali, Pulau Rakit dan daerah Plampang terjadi tanggal 19 Agustus 2018 dengan skala intensitas gempabumi pada IV - V MMI (Modified Mercally Intensity). Berdasarkan analisis pensesaran permukaan dengan pengamatan morfologi, morfotektonik, singkapan batuan, dan unsur-unsur pensesaran permukaan tidak ditemukan adanya pensesaran permukaan di Pulau Ngali, Pulau Rakit dan daerah Plampang.

\subsection{Saran/ Rekomendasi}

Adanya sesar naik yang terdapat di Teluk Saleh harus diverifikasi dengan beberapa data lainnya, yaitu data seismik refleksi dan sebaran kegempaan mikro untuk memastikan keberadaan dan tingkat aktivitas sesar naik tersebut. Sesar naik tersebut ditafsirkan dari kelurusan data anomali sisa padabasement.

\section{UCAPAN TERIMA KASIH}

Penulis mengucapkan terima kasih kepada Dr. Suparman dan Dr. Sunarko masingmasing sebagai Kepala Pusat dan Kepala Bidang Kajian Data Tapak, Pusat Kajian Sistem Energi Nuklir yang telah memberikan kesempatan penulis melakukan kegiatan lapangan dan memberikan masukan melalui diskusi.

\section{DAFTAR ACUAN}

[1]. E.A. Keller, N. Pinter, "Active Tectonic Earthquake, Uplift and Landscape, Prentice hall, Upper Saddle River”, New Jersey, 1996, p. 338.

[2]. E.A. Keller, N. Pinter, Active Tectonic Earthquake, Uplift and Landscape, Prentice hall, Upper Saddle River, New Jersey, 2002, p.362.

[3]. IAEA. SSG-35 Site Survey and Site Selection for Nuclear Installations, IAEA, 2015. 
[4]. BAPETEN, Perka BAPETEN No. 8 Tahun 2013 tentang Evaluasi Tapak Aspek Kegempaan untuk Industri Nuklir. BAPETEN. Jakarta, 2013.

[5]. Natawijaja, Evaluasi Bahaya Patahan Aktif, Tsunami dan Goncangan Gempa, Unpublished

[6]. Joko Hartadi, Sugeng Rahardjo, Oktavia Dewi Alfiani, "Pemodelan Tingkat Aktivitas Sesar Berdasarkan Analisis Deformasi Menggunakan Pengamatan GPS,", Prosiding Seminar Nasional Kebumian X, FTM-UPN Veteran, Yogyakarta,, pp.158-164, 2015.

[7]. Edi Hidayat, Puguh Dwi Raharjo, Tri Hartono, "Identifikasi Sesar Aktif di Sepanjang Kali Garang Semarang Berdasarkan Data Geologi Permukaan". Proseding Pemaparan Hasil Penelitian Puslit Geoteknologi-LIPI, pp.149-161, 2011

[8]. I.R. Pranantyo, P.R. Cummins, Multi-Data-Typ e Source Estimatio n for the 1992 Flores Earthquake and Tsunami, Pure Appl. Geophys, 176:7, pp.29692983, 2019

[9]. Daryono, "Identifikasi Sesar Naik Belakang Busur (Back Arc Thrust) Daerah Bali Berdasarkan Seismisitas dan Solusi Bidang Sesar”, Artikel Kebumian, Badan Meteorologi Klimatologi dan Geofisika, pp. 1-4. 2011

[10]. M. Asrurifak, dkk. "Development of Spectral Hazard Map for Indonesia with a Return Period of 2500 Years using Probabilistic Method”, Civil. Eng. 12:1 pp. 52-62, 2010

[11]. M Kurniawan, K N Suarba, A Septiadhi, "Analisis Risiko Bencana Gempa Bumi di Wilayah Nusa Tenggara Barat”, Bulletin Fisika Vol 18 No 1 pp. 3845, 2017.

[12]. Huzita, K, et al, "Maps of Active Faults in Japan", University of Tokyo Press, pp 73, 1992.

[13]. Mccalpin, J.P., "Paleoseismology (second edition)", Academic Press, pp. 613. 2009.

[14]. Robert Yeats, "Active Faults of the World", First Published, Cambridge University Press, pp. 600621, 2012

[15]. Supartoyo, Athanasius Cipta, Amalf Omang, Akhmad Solikhin, Pandu Adiminarno, "Munculnya Pergeseran Tanah Konsisten”, Di Balik Pesona Palu, Badan Geologi, KESDM, Cetakan Pertama, pp. 113-132, 2018.

[16]. Supartoyo, Surono, E.T. Putranto, "Katalog Gempabumi Merusak Indonesia Tahun 1612 - 2014 (Edisi Kelima)", Pusat Vulkanologi dan Mitigasi Bencana Geologi, Badan Geologi, Departemen Energi dan Sumber Daya Mineral, pp.121, 2014.

[17]. USGS, earthquake catalog. Available:https://earthquake.usgs.gov/earthquakes/ search/USGS, earthquake catalog Engdhal relocation.

Available:https://earthquake.usgs.gov/earthquakes/ browse/. Diunduh April 2019.

[18]. E.R. Engdahl, A. Villasenor, H.R. Deshon, C.H. Thurber, "Teleseismic Relocation and Assessment of Seismicity (1918 - 2005) in the Region of the $2004 \mathrm{Mw}$ 9,0 Sumatra-Andaman and $2005 \mathrm{Mw}$ 8,6 Nias Island Great Earthquakes", Bulletin of the Seismological Society of America, Vol. 97, pp.43-61 2007.

[19]. Pusat Studi Gempa Nasional (Pusgen), 2017, "Peta Sumber dan Bahaya Gempa Indonesia Tahun 2017”, Puslitbang Perumahan dan Permukiman, Balitbang Kementerian PUPR.
[20]. Pusat Survei Geologi, Badan Geologi, "Geodinamika dan Mekanisme Gempabumi Lombok", Prosiding Seminar Gempabumi Lombok di KESDM,2018, 